Proc. Estonian Acad. Sci. Biol. Ecol., 2006, 55, 1, 3-14

\title{
Comparison of communities of arbuscular mycorrhizal fungi in roots of two Viola species
}

\author{
Maarja Öpik $^{\mathrm{a}, \mathrm{b}}$, Mari Moora ${ }^{\mathrm{a}}$, Jaan Liira ${ }^{\mathrm{a}}$, Søren Rosendahl ${ }^{\mathrm{b}}$, \\ and Martin Zobel $^{\mathrm{a}}$ \\ a Institute of Botany and Ecology, University of Tartu, Lai 40, 51005 Tartu, Estonia; mari.moora@ut.ee, \\ jaan.liira@ut.ee,martin.zobel@ut.ee \\ b Institute of Biology, University of Copenhagen, Øster Farimagsgade 2D, DK-1353, Copenhagen \\ K, Denmark; soerenr@bi.ku.dk
}

Received 8 October 2004, in revised form 22 December 2004

\begin{abstract}
The composition of arbuscular mycorrhizal (AM) fungal communities in roots of rare Viola elatior and common $V$. mirabilis was investigated using PCR with primers specific for Glomus group A, followed by single-stranded conformation polymorphism analysis. Twelve AM fungal sequence types were identified, ten of them from both plant species. On average 3.8/7.5 sequence types were detected per $1 \mathrm{~cm}$-long root fragment/per plant. The frequency of individual sequence types was higher and AM fungal community composition less variable in roots of common $V$. mirabilis than rare $V$. elatior. Our results suggest quantitative differences in the AM fungal communities hosted by the two host plant species.
\end{abstract}

Key words: arbuscular mycorrhiza, molecular diversity, rare plants, SSCP, Viola, LSU rDNA, community.

\section{INTRODUCTION}

Arbuscular mycorrhizal (AM) fungi are obligate plant root symbionts present in most terrestrial ecosystems (Smith \& Read, 1997). The fungi belong to the phylum Glomeromycota (Schüßler et al., 2001), with more than 150 described species (Walker \& Trappe, 1993). Experiments with AM fungal communities of different composition and diversity have shown that the identity of fungal symbionts can determine the effect of the symbiosis on the plant populations and communities (van der Heijden et al., 1998; Moora et al., 2004). Therefore, in order to understand the causes of plant population dynamics in space and time, the dynamics of the associated AM fungal community needs to be determined along with abiotic and other biotic factors.

Corresponding author, maarja.opik@ut.ee 
The composition of AM fungal communities has long been studied on the basis of the identity of spores in natural soils or in trap cultures. Considerable variation in spore communities has been observed between plant communities (Merryweather \& Fitter, 1998; Stutz et al., 2000) and within them (Eom et al., 2000). However, spore surveys provide information regarding the infection potential of the soil, but not the AM fungal community composition in plant roots or at the site, because root-colonizing AM fungi may not be observed in the soil as spores (Clapp et al., 1995). Molecular methods are needed to obtain sufficient taxonomic resolution to describe AM fungal diversity within plant roots (reviewed by Clapp et al., 2002). Cloning of a polymerase chain reaction (PCR) product, restriction fragment length polymorphism (RFLP) screening, and sequencing of representative clones have been used successfully to describe natural AM fungal communities (e.g. Helgason et al., 1998). However, for fast screening of samples, community fingerprinting techniques such as denaturing gradient gel electrophoresis (DGGE), terminal restriction fragment length polymorphism (T-RFLP), or single strand conformation polymorphism (SSCP) can be more convenient (Kjøller \& Rosendahl, 2000; Tonin et al., 2001; Kowalchuk et al., 2002).

AM fungal species richness and diversity in plant roots can vary with the ecosystem type, with locality at landscape, community scale, host plant species, and plant age (Helgason et al., 1998, 1999, 2002; Vandenkoornhuyse et al., 2002, 2003; Husband et al., 2002a,b; Öpik et al., 2003; Wirsel, 2004; Wubet et al., 2004). Plants in the same community, e.g. a grass and a legume species, or grass species from different genera (Vandenkoornhuyse et al., 2002, 2003), or congeneric epiparasitic plant species in a community of autotrophs (Bidartondo et al., 2002) can be associated with divergent AM fungal communities. The first comparison of two congeneric autotrophic plant species with different abundances did not identify plant host related AM fungi or AM fungal community patterns (Öpik et al., 2003).

The objective of the present study was to compare the composition of AM fungal communities in the roots of two related plant species showing different abundances. We ask: What is the community structure of AM fungi colonizing the roots of rare Viola elatior and common Viola mirabilis?

\section{MATERIAL AND METHODS}

\section{Plant species}

Viola elatior Fr. is a perennial forb growing on mesic calcareous soils in wooded meadows and sparse deciduous forests. The species is distributed from central Europe to the mountains of central Asia, though the Asiatic distribution is not fully known (Hultén \& Fries, 1986). Viola mirabilis L. is a perennial forb that prefers habitats with mesic calcareous soil - grasslands, wooded meadows, and deciduous and mixed forests (Kukk, 1999). The species is distributed in central and eastern Europe and western Asia (Hultén \& Fries, 1986). 
Despite relatively similar ecology and morphology, these two species show contrasting abundances in Estonia (Kukk, 1999) - V. mirabilis is widespread while $V$. elatior is only found at 13 localities (December 2003, T. Kull, database of Distribution Maps of Estonian Vascular Plants, Institute of Zoology and Botany, Estonian Agricultural University).

\section{Study sites and sampling}

Plant roots were sampled from five sites, the details of which are given in Table 1 . Sites 1, 2, and 3 are located within a circle of $10 \mathrm{~km}$; the distance to other sites was over $100 \mathrm{~km}$. Roots of $V$. mirabilis and $V$. elatior were collected in September 1999. The whole root system of a sample plant was excavated, washed, and stored in $50 \%$ ethanol at $4{ }^{\circ} \mathrm{C}$. Two individuals of each study species present at a site were sampled. From each individual, six $1 \mathrm{~cm}$-long fragments of fine roots were randomly taken for molecular analysis.

\section{Fungal isolates}

Single spores of Glomus mosseae (T. H. Nicholson \& Gerd.) Gerd. \& Trappe (isolate BEG84), G. caledonium (T. H. Nicholson \& Gerd.) Gerd. \& Trappe (BEG86), and G. geosporum (T. H. Nicholson \& Gerd.) C. Walker (BEG90) were used as reference taxa in SSCP.

\section{DNA extraction, PCR, and SSCP}

DNA was extracted from a total of 96 root pieces ( 60 samples of $V$. mirabilis and 36 samples of $V$. elatior) by the Chelex extraction method (van Tuinen et al., 1998). DNA was extracted from spores of reference fungi by washing the spores twice in sterile water and crushing them in $50 \mu \mathrm{L}$ TE buffer. After centrifugation $(5 \mathrm{~min}, 14000 \mathrm{~g})$ the supernatant was directly used in PCR. Nested PCR, with eukaryote specific primers LSU 0061/LSU 0059 (LR1/NDL22, van Tuinen et al., 1998) in the primary PCR reaction, and specific primers LSURK4f/LSURK7r (Kjøller \& Rosendahl, 2000) in the nested reaction, was performed as in Kjøller \& Rosendahl (2000), except that the primary PCR product was diluted 1:100 prior to use in the nested reaction. Products of positive nested PCR reactions (77 samples: $52 \mathrm{~V}$. mirabilis, $25 \mathrm{~V}$. elatior samples) were analysed by SSCP electrophoresis (Kjøller \& Rosendahl, 2000). SSCP gels were run for $3 \mathrm{~h}$ at $4{ }^{\circ} \mathrm{C}$ using Hoefer Mighty Small ${ }^{\mathrm{TM}}$ II SE 250 horizontal gel electrophoresis units (Hoefer Scientific Instruments, San Francisco, CA). Gels were stained by silver staining using the PlusOne DNA Silver Staining Kit (Amersham Pharmacia Biotech, UK).

The SSCP banding patterns obtained from different root samples were compared by eye, and the bands were grouped according to similar mobility. Usually, two 


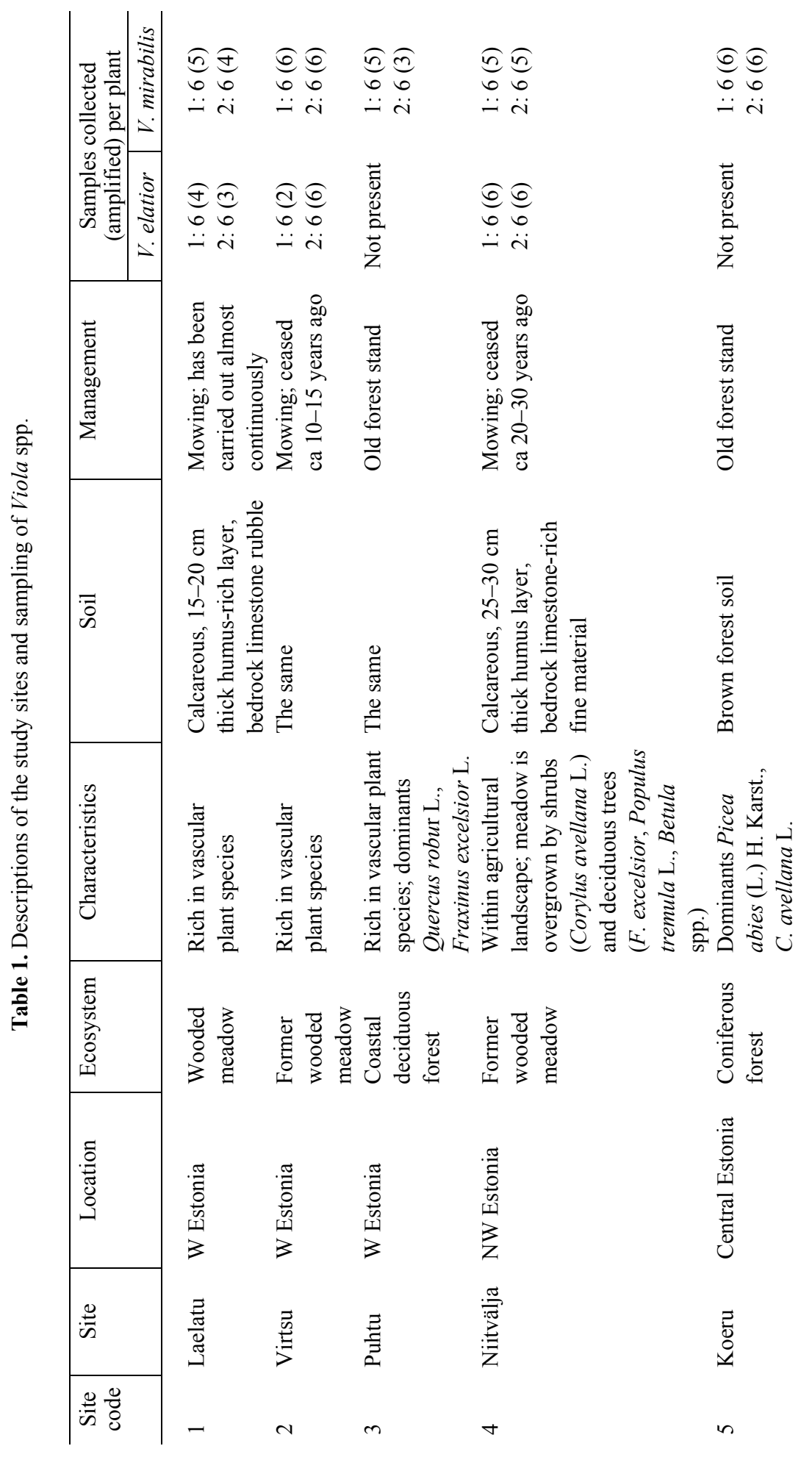


bands occurring close to each other were recognized as a sequence group, presuming that two single strands of the same DNA fragment have folded up in distinct conformations and have moved at slightly different speeds. If only a single band was present it was seen as a separate group, presuming that two single strands have folded up in one conformation due to a particular combination of nucleotides. In cases where gel-to-gel comparisons of band positions were hard to make, the samples from different gels were re-run together.

\section{Statistical data analysis}

The ordination analysis of AM fungal communities in plant roots was performed separately with the data set of 1-cm-long root samples (sequence types detected/ not detected) and the data set of the whole plant individuals (detection frequencies of sequence types) using detrended correspondence analysis (DCA), implemented in PC-ORD 4.01 (McCune \& Mefford, 1999). The effect of plant species and study site on the AM fungal sequence type richness per plant was estimated using two-way ANOVA with mixed factors and Tukey's HSD test in SAS 6.12 (Littell et al., 1996). In the mixed model of sequence type richness in 1-cm-long root fragments, the plant individual was considered as a random factor.

\section{RESULTS}

\section{Occurrence of AM fungal sequence types in Viola spp. roots}

We compared the SSCP patterns of nested PCR products of AM fungal LSU rDNA from root samples of Viola mirabilis and V. elatior with each other and identified fungal sequence types by band mobility (position) in the gel. Altogether, 12 AM fungal sequence types were recognized from root samples (Table 2). SSCP fingerprints of single spores of Glomus mosseae, G. geosporum, and G. caledonium isolates were compared with those of our root samples, but no similar patterns were identified (not shown). This implies that these particular fungal isolates were not present in the study plants.

\section{Ordination analysis of $\mathrm{AM}$ fungal communities}

In the ordination of root samples of individual plants by DCA, the first two axes described $45.3 \%$ of the total variation in the AM fungal community composition (Fig. 1). The root samples of $V$. elatior plants had a higher dispersion along the first and the second DCA axes, the samples of $V$. mirabilis varied mostly along the first axis. The DCA ordination highlights the greater similarity of $V$. mirabilis root AM fungal communities within and between sites. Conversely, $V$. elatior samples were scattered near the margins of the ordination plane, showing greater dissimilarity within and between sites. Plants from the same site tended to be 


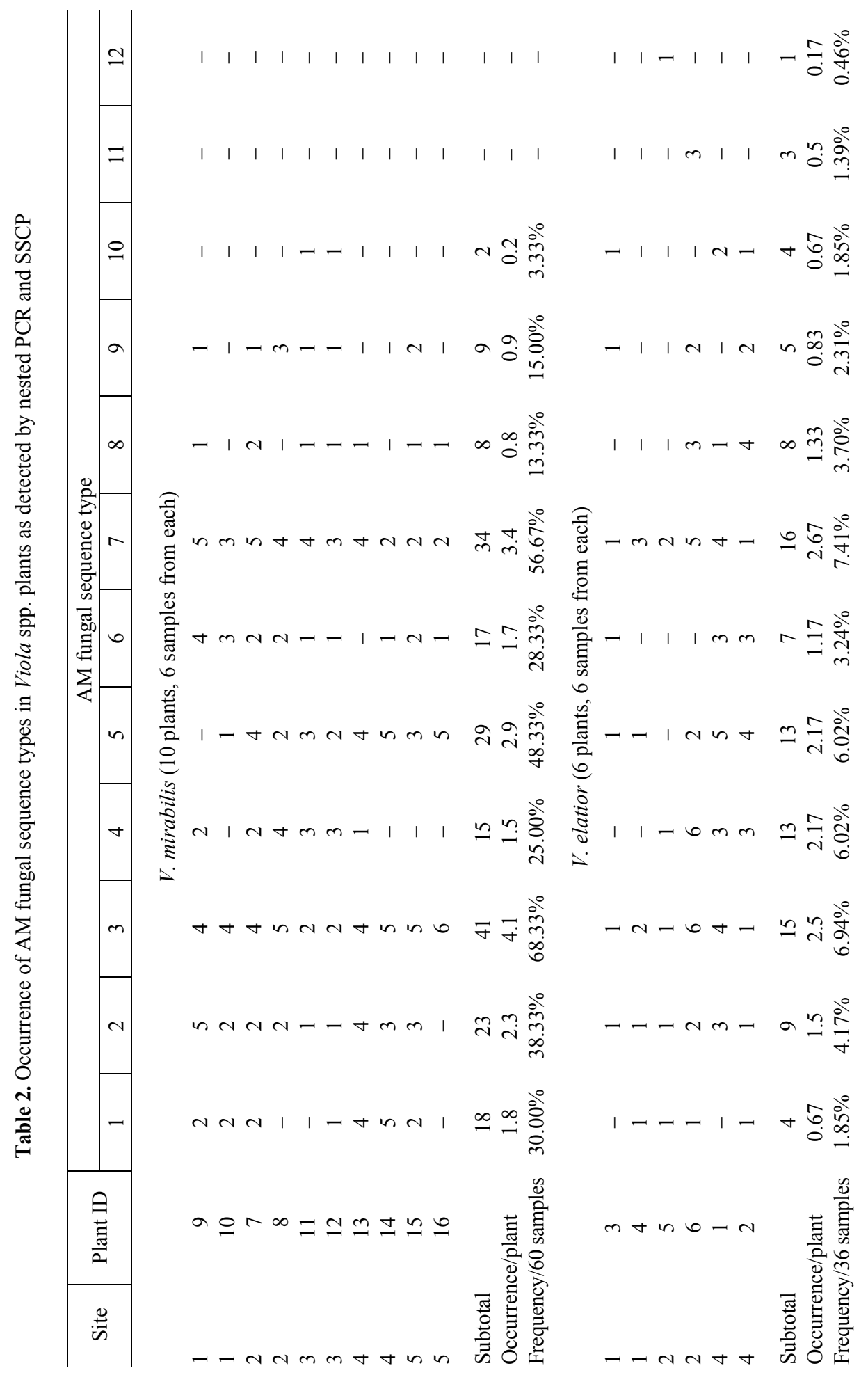




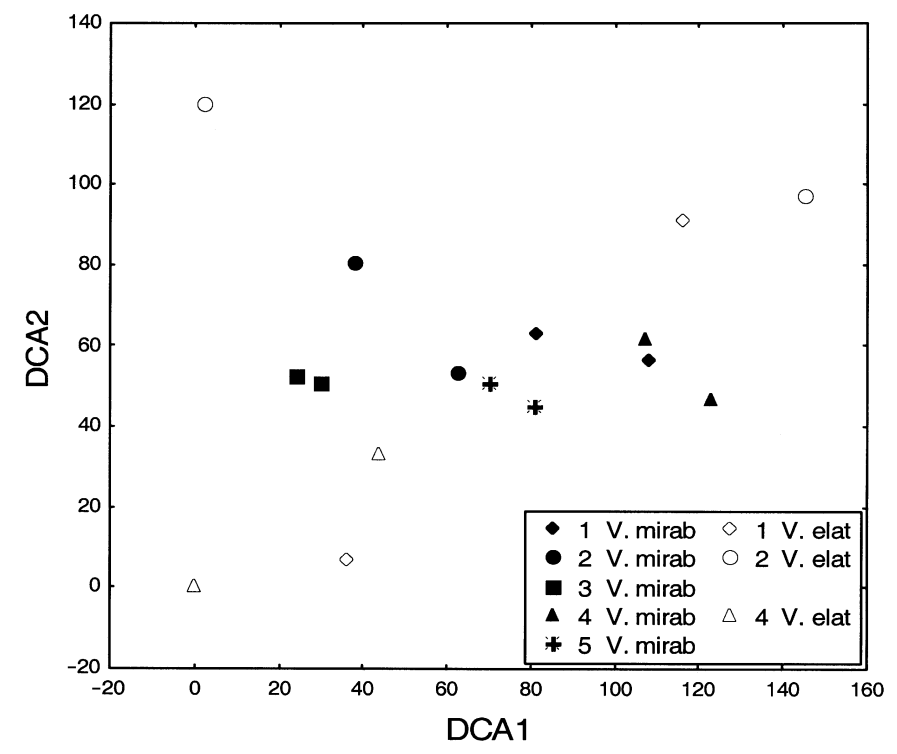

Fig. 1. DCA ordination showing the differences in AM fungal communities between host plants, plant species, and sites. Each point represents an AM fungal community in the root system of a plant described by fungal sequence type frequencies, identified by site (numbered 1 to 5 as in Table 1) and species (filled symbols, V. mirab - V. mirabilis; open symbols, V. elat $-V$. elatior). The DCA axes $1-2$ describe $45.3 \%$ of variation $(1-35.1 \%, 2-10.2 \%)$.

located close to one another on the ordination plane, more regularly in the case of $V$. mirabilis and less so in the case of $V$. elatior. No regular pattern was apparent for the study sites.

DCA for AM fungal presence/absence in 1-cm-long root fragments showed the samples from individual plants to be scattered over the ordination plane (ordination diagram not shown), suggesting considerable variation in the AM fungal community within root systems, whereas total variation between plants was much smaller.

\section{AM fungal sequence type richness}

AM fungal sequence type richness per 1-cm root fragment (3.8 types on average, max 8 types) and per plant (7.5 types on average, max 10 types) was not significantly different between plant species or sites. However, there was a significant interaction $(F=5.19, P=0.008)$ between plant species and site in the case of root fragment data. Root fragments of $V$. elatior contained significantly fewer sequence types in site 1 as compared to site 2 (Tukey's HSD test, $P<0.05$ ). This difference vanished $(F=1.59, P=0.262)$ when the AM fungal diversity in the whole plant individual was considered. 


\section{DISCUSSION}

The present attempt to screen the distribution of AM fungi colonizing the roots of two Viola species in their natural habitats revealed an interesting pattern. Similarly to some earlier surveys (Helgason et al., 2002; Husband et al., 2002a,b), we identified a group of constant AM fungal sequence types, 8 of 12 detected types, which occurred in the roots of most plants of both species in all study sites (Table 2). Hence, there was a stable component in AM fungal communities, which did not vary over the whole sample set studied. The distribution of the remaining fungal types was more variable.

The variability of the AM fungal community composition was considerably higher among the plants of $V$. elatior, in contrast to the more similar fungal communities of $V$. mirabilis. This was apparent from the $V$. elatior plants occupying peripheral positions in the DCA analysis, surrounding the centrally located V. mirabilis samples (Fig. 1). In part, such a distinction between the two plant species is explained by the occurrence of rare fungal types that colonized only, or preferably, the roots of $V$. elatior (Table 2, sequence types $10,11,12$ ).

Different levels of compatibility can exist between AM fungi and plant species from the same community (Bidartondo et al., 2002; Helgason et al., 2002; Vandenkoornhuyse et al., 2002, 2003). Uniquely among AM fungi, strict specificity was identified between epiparasitic plants and their AM fungal symbionts (Bidartondo et al., 2002). On the contrary, coexisting congeneric green plant species did not exhibit species-related differences in their AM fungal communities (Öpik et al., 2003). In the present study, most of the observed differences between AM fungal communities of Viola plants were quantitative, i.e. the same fungal types colonized the two Viola species with different frequencies (Table 2). Given the relatively similar AM fungal sequence type pools in the study sites, the data suggest a certain host-plant effect on colonization.

Communities of AM fungi have been shown to vary within and between sites (Helgason et al., 1999; Vandenkoornhuyse et al., 2002; Öpik et al., 2003; Wirsel, 2004). In the present study, the little variation observed between sites could be attributable to the small sample size and/or the applied methodology (Kjøller \& Rosendahl, 2000, 2001) identifying just a subgroup of AM fungi in the Glomus group A (Schwarzott et al., 2001). Though, in many studies, the major diversity of AM fungi detected in the field is classified to Glomus group A (Helgason et al., 1998, 1999; Vandenkoornhuyse et al., 2002; Öpik et al., 2003), the presence of other AM fungal groups in the studied Viola plant roots is highly probable.

The AM fungi used as reference taxa in SSCP (G. caledonium, G. geosporum, G. mosseae; isolated from arable fields in Denmark, Kjøller \& Rosendahl, 2000), were not detected in our root samples. The presence of the same species, however, cannot be ruled out because of the variability of the studied gene region. Choice of reference isolates originating from the same site or from a similar ecosystem is highly advisable in future studies; however, such isolates were not available at the time this study was conducted, therefore we selected some of the isolates that were used to design the SSCP approach (Kjøller \& Rosendahl, 2000). 
The AM fungal sequence types, as recognized by us, may represent fungal species or isolates (Kjøller \& Rosendahl, 2000), or intra-isolate polymorphic sequences (Clapp et al., 2001). Further, some SSCP patterns recognized as sequence types might have actually been alternative conformations of one sequence type. Reading the SSCP patterns of complex samples clearly introduces a further degree of subjectivity. Though the method is excellent for the pre-sequencing screening of samples containing just one sequence type, or for monitoring or detection of small numbers of species (Kristiansen et al., 2001), readability of patterns from field samples containing several sequence types is fairly complicated. These aspects could also explain the relatively high number of different sequence types detected in some 1-cm root samples. A similar SSCP approach has been applied to samples from an agricultural field, utilizing even narrower group-specific primers of the LSU region (Jansa et al., 2003), which obviously helps to overcome the complexity of SSCP patterns. Thus, we are aware that with no further information, including sequence data, the current fungal community description is rather preliminary.

We did not identify any clear pattern of AM fungal sequence type richness per plant individual. The sequence type richness per site ( $8-11$ types) was higher than previously identified in a seminatural woodland (5 types in Glomus group A, Helgason et al., 2002) and boreal forest (6 types, Öpik et al., 2003), similar to a fragmented grassland in Estonia (12 types, Öpik et al., 2003), and smaller than in an upland grassland in the UK (18 types, Vandenkoornhuyse et al., 2002). Still, as different methods and gene regions were used, these figures are not directly comparable.

Besides the sequence type richness, the AM fungal community composition in 1 -cm-long root fragments was highly variable, suggesting that the fungi occupied different spatial niches in the root system. Comparable results have been obtained with Medicago truncatula co-inoculated with three AM fungi in a pot experiment, showing the presence of Gigaspora rosea in $20 \%$ of $1-\mathrm{cm}-$ long root pieces, Glomus intraradices in $70 \%$, and G. mosseae in $100 \%$ of root fragments of a single plant (Jacquot et al., 2000); M. truncatula or Fragaria vesca in metal-contaminated field sites, with the majority of 1-cm-long root samples being colonized by one or two AM fungal species, and only a few samples by all five fungi detected in the respective fungal communities (Jacquot-Plumey et al., 2001; Turnau et al., 2001); and Pisum sativum in an arable field (Kjøller \& Rosendahl, 2001), with most of the 0.5 -cm-long root pieces being colonized by one, and a few by two sequence groups. In the present study, the naturally growing Viola species demonstrated higher small-scale AM fungal diversity - three to four fungal types per 1-cm root fragment on average.

The results of this study suggest that the two studied plant species may obtain symbiotic fungal communities of different structure and variability from the same fungal sequence type (species) pool, indicative of dissimilar levels of specificity between the plant hosts and fungal symbionts. 


\section{ACKNOWLEDGEMENTS}

This study was supported by a scholarship from The Danish Rectors' Conference (MÖ), a grant from the Maj and Tor Nessling Foundation, a grant from the Estonian Science Foundation (GBGBO 4579), and a grant from the Danish Science Research Council. I. Part kindly helped with language correction.

\section{REFERENCES}

Bidartondo, M. I., Redecker, D., Hijri, I., Wiemken, A., Bruns, T. D., Dominguez, L., Sérsic, A., Leake, J. R. \& Read, D. J. 2002. Epiparasitic plants specialized on arbuscular mycorrhizal fungi. Nature, 419, 389-392.

Clapp, J. P., Young, J. P. W., Merryweather, J. W. \& Fitter, A. H. 1995. Diversity of fungal symbionts in arbuscular mycorrhizas from a natural community. New Phytol., 130, 259-265.

Clapp, J. P., Rodriguez, A. \& Dodd, J. C. 2001. Inter- and intra-isolate rRNA large subunit variation of Glomus coronatum spores. New Phytol., 149, 539-554.

Clapp, J. P., Helgason, T., Daniell, T. J. \& Young, J. P. W. 2002. Genetic studies of the structure and diversity of arbuscular mycorrhizal fungal communities. In Mycorrhizal Ecology (van der Heijden, M. G. A. \& Sanders, I., eds), pp. 201-224. Springer, Berlin, Heidelberg, New York.

Eom, A.-H., Hartnett, D. C. \& Wilson, G. W. T. 2000. Host plant species effects on arbuscular mycorrhizal fungal communities in tallgrass prairie. Oecologia, 122, 435-444.

Helgason, T., Daniell, T. J., Husband, R., Fitter, A. H. \& Young, J. P. W. 1998. Ploughing up the wood-wide web? Nature, 394, 431.

Helgason, T., Fitter, A. H. \& Young, J. P. W. 1999. Molecular diversity of arbuscular mycorrhizal fungi colonising Hyacinthoides non-scripta (bluebell) in a seminatural woodland. Mol. Ecol., 8, 659-666.

Helgason, T., Merryweather, J. W., Denison, J., Wilson, P., Young, J. P. W. \& Fitter, A. H. 2002. Selectivity and functional diversity in arbuscular mycorrhizas of co-occurring fungi and plants from a temperate deciduous woodland. J. Ecol., 90, 371-384.

Hultén, E. \& Fries, M. 1986. Atlas of North European Vascular Plants: North of the Tropic of Cancer. Koeltz Scientific Books, Königstein.

Husband, R., Herre, E. A., Turner, S. L., Gallery, R. \& Young, J. P. W. 2002a. Molecular diversity of arbuscular mycorrhizal fungi and patterns of host association over time and space in a tropical forest. Mol. Ecol., 11, 2669-2678.

Husband, R., Herre, E. A. \& Young, J. P. W. 2002b. Temporal variation in the arbuscular mycorrhizal communities colonising seedlings in a tropical forest. FEMS Microbiol. Ecol., 42, 131-136.

Jacquot, E., van Tuinen, D., Gianinazzi, S. \& Gianinazzi-Pearson, V. 2000. Monitoring species of arbuscular mycorrhizal fungi in planta and in soil by nested PCR: application to the study of the impact of sewage sludge. Plant Soil, 226, 179-188.

Jacquot-Plumey, E., van Tuinen, D., Chatagnier, O., Gianinazzi, S. \& Gianinazzi-Pearson, V. 2001. 25S rDNA-based molecular monitoring of glomalean fungi in sewage sludge-treated field plots. Environ. Microbiol., 3, 525-531.

Jansa, J., Mozafar, A., Kuhn, G., Anken, T., Ruh, R., Sanders, I. R. \& Frossard, E. 2003. Soil tillage affects the community structure of mycorrhizal fungi in maize roots. Ecol. Appl., 13, 1164 1176.

Kjøller, R. \& Rosendahl, S. 2000. Detection of arbuscular mycorrhizal fungi (Glomales) in roots by nested PCR and SSCP (single stranded conformation polymorphism). Plant Soil, 226, 189-196.

Kjøller, R. \& Rosendahl, S. 2001. Molecular diversity of glomalean (arbuscular mycorrhizal) fungi determined as distinct Glomus specific DNA sequences from roots of field grown peas. Mycol. Res., 105, 1027-1032. 
Kowalchuk, G. A., de Souza, F. A. \& Van Veen, J. A. 2002. Community analysis of arbuscular mycorrhizal fungi associated with Ammophila arenaria in Dutch coastal sand dunes. Mol. Ecol., 11, 571-581.

Kristiansen, K. A., Taylor, D. L., Kjøller, R., Rasmussen, H. N. \& Rosendahl, S. 2001. Identification of mycorrhizal fungi from single pelotons of Dactylorhiza majalis (Orchidaceae) using single-strand conformation polymorphism and mitochondrial ribosomal large subunit DNA sequences. Mol. Ecol., 10, 2089-2093.

Kukk, T. 1999. Eesti taimestik. Teaduste Akadeemia Kirjastus, Tallinn.

Littell, R. C., Milliken, G. A., Stroup, W. W. \& Wolfinger, R. D. 1996. SAS® System for Mixed Models. SAS Institute Inc., Cary, NC.

McCune, B. \& Mefford, M. J. 1999. PC-ORD. Multivariate Analysis of Ecological Data, Version 4. MjM Software Design, Gleneden Beach, Oregon.

Merryweather, J. \& Fitter, A. 1998. The arbuscular mycorrhizal fungi of Hyacinthoides non-scripta II. Seasonal and spatial patterns of fungal populations. New Phytol., 138, 131-142.

Moora, M., Öpik, M., Sen, R. \& Zobel, M. 2004. Native arbuscular mycorrhizal fungal communities differentially influence the seedling performance of rare and common Pulsatilla species. Funct. Ecol., 18, 554-562.

Öpik, M., Moora, M., Liira, J., Kõljalg, U., Zobel, M. \& Sen, R. 2003. Divergent arbuscular mycorrhizal fungal communities colonize roots of Pulsatilla spp. in boreal Scots pine forest and grassland soils. New Phytol., 160, 581-593.

Schüßler, A., Schwarzott, D. \& Walker, C. 2001. A new fungal phylum, the Glomeromycota: phylogeny and evolution. Mycol. Res., 105, 1413-1421.

Schwarzott, D., Walker, C. \& Schüßler, A. 2001. Glomus, the largest genus of the arbuscular mycorrhizal fungi (Glomales), is nonmonophyletic. Mol. Phylogen. Evol., 21, 190-197.

Smith, S. E. \& Read, D. J. 1997. Mycorrhizal Symbiosis. 2nd ed. Academic Press, London.

Stutz, J. C., Copeman, R., Martin, C. A. \& Morton, J. B. 2000. Patterns of species composition and distribution of arbuscular mycorrhizal fungi in arid regions of southwestern North America and Namibia, Africa. Can. J. Bot., 78, 237-245.

Tonin, C., Vandenkoornhuyse, P., Joner, E. J., Straczek, J. \& Leyval, C. 2001. Assessment of arbuscular mycorrhizal fungi diversity in the rhizosphere of Viola calaminaria and effect of these fungi on heavy metal uptake by clover. Mycorrhiza, 10, 161-168.

Turnau, K., Ryszka, P., Gianinazzi-Pearson, V. \& van Tuinen, D. 2001. Identification of arbuscular mycorrhizal fungi in soils and roots of plants colonizing zinc wastes in Poland. Mycorrhiza, 10, 169-174.

van der Heijden, M. G. A., Boller, T., Wiemken, A. \& Sanders, I. R. 1998. Different arbuscular mycorrhizal fungal species are potential determinants of plant community structure. Ecology, 79, 2082-2091.

van Tuinen, D., Zhao, B. \& Gianinazzi-Pearson, V. 1998. PCR in studies of AM fungi: from primers to application. In Mycorrhiza Manual (Varma, A., ed.), pp. 387-400. Springer, Berlin.

Vandenkoornhuyse, P., Husband, R., Daniell, T. J., Watson, I. J., Duck, J. M., Fitter, A. H. \& Young, J. P. W. 2002. Arbuscular mycorrhizal community composition associated with two plant species in a grassland ecosystem. Mol. Ecol., 11, 1555-1564.

Vandenkoornhuyse, P., Ridgway, K. P., Watson, I. J., Fitter, A. H. \& Young, J. P. W. 2003. Coexisting grass species have distinctive arbuscular mycorrhizal communities. Mol. Ecol., 12, 3085-3095.

Walker, C. \& Trappe, J. M. 1993. Names and epithets in the Glomales and Endogonales. Mycol. Res., 97, 339-344.

Wirsel, S. G. R. 2004. Homogenous stands of a wetland grass harbour diverse consortia of arbuscular mycorrhizal fungi. FEMS Microbiol. Ecol., 48, 129-138.

Wubet, T., Weiss, M., Kottke, I., Teketay, D. \& Oberwinkler, F. 2004. Molecular diversity of arbuscular mycorrhizal fungi in Prunus africana, an endangered medicinal tree species in dry Afromontane forests of Ethiopia. New Phytol., 161, 517-528. 


\title{
Arbuskulaar-mükoriissete seente koosluste võrdlus kahe kannikeseliigi (Viola spp.) juurtes
}

\author{
Maarja Öpik, Mari Moora, Jaan Liira, Søren Rosendahl ja Martin Zobel \\ On uuritud arbuskulaar-mükoriissete (AM) seente koosluste koosseisu haruldase \\ kõrge kannikese (Viola elatior) ja tavalise imekannikese (V. mirabilis) juurtes, \\ kasutades PCR-i perekonna Glomus rühmale A spetsiifiliste praimeritega ja ühe- \\ ahelalise konformatsiooni-polümorfismi (SSCP) analüüsi. Kokku on määratud 12 \\ AM-seene järjestustüüpi, neist 10 esines mõlema taimeliigi juurtes. Keskmiselt \\ on kindlaks tehtud 3,8/7,5 järjestustüüpi $1 \mathrm{~cm}$ pikkuses juurelõigus/ühe taime juu- \\ restikus. Võrreldes haruldase liigiga $V$. elatior, on tavalise liigi $V$. mirabilis juurtes \\ AM-i järjestustüüpide esinemissagedus suurem ja AM-i seenekoosluse koosseis \\ vähem varieeruv. Töö tulemused viitavad AM-i seenekoosluste kvantitatiivsetele \\ erinevustele uuritud kahe taimeliigi juurtes.
}

